\title{
Socio-Political Significance of Herodotos' Hybris and Phthonos and Thucydides' Rule of Power and Tyche
}

\author{
By Jayoung Che
}

Hybris (arrogance) and the states potentially caused by hybris, phthonos (zealousy or envy), and ate (disaster) or nemesis (punishment), in Herodotus frequently are attributed to Xerxes. And hybris does not refer to the monarchic domination itself, but the ambition for an excessive scale of territory. A king's conquest used to result in a temporary increase of military power, and the power of Persia was almost irresistible, many times greater than the target of its conquest. Once the conquest was completed and the king's sovereignty recognized, however, his rule pretended to follow conventional usage. And the ruled under the king were regarded as 'king's slaves,' who were dominated not necessarily under the oppression and control of standing army. Thucydides hybris, however, refers to the Athenians as a community. The target of Athenian's conquest was not the slaves, and the military forces of the Athenian rivals were a close match for the Athenians. So the Athenian militaristic hegemony could be sustained only by superiority of military power, irrelevant to any traditional custom. In this kind of balance of power, human errors or insolence could bring about fatal disasters much more in war time than in peace, as human mistakes bear more risk in the situation of war. And, different from the Persian king's ambition for a larger territory, the principle, 'rule of power' as a natural law, applicable even to small area, irrelevant of territorial extent. The punishment in Herodotos was inflicted by deity against the hybris committed by individuals, but in Thucydides by Tyche (Fortune) which alters situations unexpectedly and causes disaster to a community, irrelevant of whether one commits hybris or not.

\section{Introduction}

At the beginning of the $20^{\text {th }}$ century, F.M. Cornford defined Thucydides as a Myth-Writer (Mythistoricus), pointing out that Thucydides was deeply influenced by religious/tragic patterns. His Thucydides Mythistoricus presented the decline of Athens as a set of dramatic and tragic stories about the

\footnotetext{
*Assistant Professor, Busan University of Foreign Studies, Republic of Korea.
} 
punishment of hybris. ${ }^{1}$ And, Cornford says, though the gods played no part in history, an element of the incalculable nevertheless remained, he called this element chance, tyche. ${ }^{2}$

Similar to Cornford, Lloyd-Jones suggested that Thucydides sees the history of the Empire in tragic terms, however, not necessarily because he has been influenced by tragedy but more probably because similar to the tragedians, such as Herodotos, like most of his contemporaries his mind was profoundly conditioned by the epic. According to him, Greeks who believed in divine agencies held, from Homer's time on, that they influenced war not from the outside but from the inside, through human passions upon human minds.. ${ }^{3}$

De Romilly however pointed out 'the Law of Hybris' as a part of Thucydides' psychological explanation of the mistakes of imperial powers like Athens, but sees him working out these themes entirely in nonreligious terms. ${ }^{4}$ That is, men are carried away by success, conceive excessive desires, and make significant mistakes due to greed. This psychological pattern is found in the poets and Herodotos, but, according to her, Thucydides offers a secular analysis in place of traditional religious ideas. According to de Romilly, although 'excess, or hybris' is very familiar to the Greeks, this word is not very often used by Thucydides (cf. 3.39.4, 1.84.2), but it is sufficiently frequent for us to know what it means. ${ }^{5}$

Also, according to Fisher there is absolutely nothing in the contexts in which Thucydides uses the term hybris to suggest that use of that term in itself aroused expectations of divine hostility. ${ }^{6}$ Fisher says, Thucydides distances

${ }^{1}$ F.M. Cornford, Thucydides Mythistoricus (London, 1907/1965), 129ff. ; cf. L.S. Gustafson, Thucydides Theory of International Relations (Luisiana.: 2000), p.6.

${ }^{2}$ F.M. Cornford, Thucydides Mythistoricus, p.312.

${ }^{3}$ H. Lloyd-Jones, Justice of Zeus (Berkely/ Los Angeles, 1973), p.143f. He says, we cannot be certain if Thucydides is a Protagorean agnostic. But the question as to whether he believed in the gods or not is not one of any great significance, for if he did reject them, it was the Greek Gods, not any other gods whom he rejected. The world as he presents it, like the world presented by Herodotos, is a hard and ruthless world, and it is the world of the traditional Greek religion. Cf. J.H. Finley[Thucydides (Michigan, 1967), p.323f.] forwarded the suggestion that Thucydides juxtaposed scenes of quite opposite import, for instance, the Funeral Oration and the plague, the insolent Melian Dialogue and the crushing defeat at Syracuse. But, he says, it is a drama that is based on confidence in men's power, played on a purely mundane level. As a result, according to him, the substance of the tragic pattern is the substance of history, not of drama. N. Marinatos [Thucydides and Religion (Konigstein, 1981); cf. N. Marinatos Kopff \& H.R. Rawlings, 'Panolethria and Divine Punishment: Thuc.7.87.6 and Hdt.2.120.5,' PP 33 (1978), pp.331-337], however, insisted that, even if there were the betrayal of tyche, as well as some of the military and political reasons, for the Athenian defeat, another reason, on a different plane, also intervenes in the disaster. And it is the punishment of god, a powerful metaphysical force, for the terrible injustice, even though there is no Herodotean gods in Thucydides.

${ }^{4}$ J. de Romilly, Thucydides and Athenian Imperialism (Oxford, 1963), p.327f. Cf. N.R.E. Fisher, Hybris (Teddington, 1992), p.391.

${ }^{5}$ Cf. J. de Romilly, Thucydides and Athenian Imperialism, p. 322.

${ }^{6}$ N.R.E. Fisher, Hybris, p.407f. Cf. Fisher traces the use of the concept hybris in literature and law from the time of Homer to that of Plato. He (ibid. 5f.) argues that hybris as well as time and aidos are the individual's own sense of personal honor and shame. According to him, the essence of hybris is the deliberate infliction of dishonor and shame upon others, and it is not, as 
himself from Nicias' and the troops' religiosity in relation to divination, the feeling that the gods are working to punish (and his position, at least in the portion of his work written later than 416 B.C., is closer to that of the Athenians at Melos, 5.103). ${ }^{1}$ He says, the Sicilian expedition could easily be seen as a clear case of the hybris of the imperial power seeking to extend its dominance, but diagnosis of a case of hybris must be separated from the question of whether subsequent disaster needs to be seen as (divine) punishment. He argued that hybris is merely one element, and not the whole. The Sicilian expedition was not doomed to failure from the beginning, ${ }^{2}$ and the Athenians' error in their moments of success have contributed to, but do not fully explain or justify, the most spectacular disaster, a disaster to a great empire, to whose merits and demerits Thucydides has devoted obsessive, if fundamentally ambivalent, concern. ${ }^{3}$

The role of hybris has been explained in different ways; to be punished in a religious, tragic pattern, or non religious, psychological pattern, or its role reduced to one of many causes bringing about disaster. This essay, however, is to review the meaning of Thucydides' hybris by comparison with that of Herodotos. The focus is not on whether any divinity or super-natural power intervenes in the tragic pattern of hybris-nemesis. And, in cases where hybris is regarded as being concerned with mundane things, the two historians differ with each other in regard to the concept of insolence causing disaster. It is due, in my opinion, to the difference of socio-political structures with which each historian dealt.

In the Persia Herodotos described, power was given to the king, and hybris refers inevitably to the individual monarch. Thucydides, however, focused on the people's insolence in Athens, consequently hybris referring to a community. Furthermore, in Herodotos hybris is to be mastered by punishment

commonly thought, a special form of pride or self-confidence which offends the gods and is characteristic of tragic heroes.

${ }^{1}$ N.R.E. Fisher, Hybris (Teddington, 1992) p.406f. Cf. Thucydides, 5.103 ، ... Let not this be the case with you, who are weak and hang on a single turn of the scale; nor be like the vulgar, who, abandoning such security as human means may still afford, when visible hopes fail them in extremity, turn to invisible, to prophecies and oracles, and other such inventions that delude men with hopes to their destruction..'. According to Fisher, Thucydides carefully distances from Nicias' and the troops' religiosity in relation to divinity and Thucydides' presentation of other religious beliefs do not in themselves encourage belief that he favored acceptance of such patterns.

${ }^{2}$ N.R.E. Fisher, Hybris (Teddington, 1992) p.393.

${ }^{3}$ Fisher (Hybris, (Teddington, 1992) pp.409-410) contradicted the following three claims: 1 the punishment was appropriate and inevitable. 2- this appropriate result is the most striking or important element in Thucydides. 3- That makes the sequence of episodes especially tragic in the sense of crimes punished. According to Fisher, what is essentially tragic is precisely not that power figures or states meet a just fall in recompense for their major crimes. In a similar context, C.W. Macleod[Collected Essays (Oxford, 1983), Ch.13 says that the patterns of events involving Pylos, Melos and Sicily are 'truly tragic' because the Athenians error in their moments of success have contributed to, but do not fully explain or justify, the most spectacular disaster, which itself played a significant part in the downfall of a great empire, to whose merits and demerits Thucydides has devoted obsessive, if fundamentally ambivalent, concern.. 
(ate or nemesis) or envy (phthonos), but in Thucydides by Fortune (tyche), which is more variable and unpredictable.

\section{Individual Persian King and the Athenians as a Community}

As Herodotos describes the insolent behaviors of individual Persian kings, Momigliano maintains that, granted the improbability of the Greeks going beyond the most overt aspects of Persian life because of a lack of linguistic ability, it was inevitable that some Persian kings should be found more guilty than others of overweening pride, hybris. ${ }^{1}$ Then, pride, according to Momigliano, was an individual, not an institutional, characteristic. Attention was therefore diverted from Persian institutions to the individual attitudes of the Persian kings. Moreover, he emphasized the role of the demon in the dreams with which the gods counselled to increase pride. So, he asserted, Xerxes' arrogance is not so much a sin as an indication of divine punishment. ${ }^{2}$

Fisher, however, contradicted Momigliano, saying that we should consider hybris in Artabanos' speech to Xerxes rather as the imperialist drives and attitudes, the yearning to conquer and impose further slavery. ${ }^{3}$ The potential hybris was to be ascribed to the Persian imperial as a whole rather than merely to the individual king, and indeed as a growing element in the 'policystructures' and the traditions of the Persian Empire as a whole.

As Fisher properly pointed out, the attitudes of Persian kings were not excluded from the Persian institution. In my opinion, however, Fisher did not advance to the point that the Persian institutions differed to those of Athens. He overlooked the importance of the Persian political system which gave power to the monarch. The Persians themselves knew that not only the tyrant but the populace could become a victim to hybris, since human nature is one and the same without exception. It is shown in Megabyzos' discussion for supporting oligarchy. According to Megabyzos, whatever the tyrant does, he does with knowledge, but for the populace knowledge is impossible

Herodotos, 3.81. “... but Megabyzos urged that they resort to an oligarchy. "I agree," said he, "with all that Otanes says against the rule of one; but when he tells you to give the power to the multitude, his judgment strays from the best. Nothing is more foolish and violent than a useless mob; [2] for that men fleeing the insolence of a tyrant to fall victim to the insolence of the unguided populace are by no means to be tolerated. Whatever the one does, he does with knowledge, but for the other knowledge is impossible; how can they have knowledge. They have not learned or seen for themselves what is best, but always rush headlong and drive blindly onward, like a flooded river? [3] As for the people, then, let them govern Persia's enemies; but let us choose a group of

\footnotetext{
${ }^{1}$ A. Momigliano, 'Persian Empire and Greek Freedom,' in The Idea of Freedom: Essays in Honour of Isaiah Berlin, Alan Ryan ed. (Oxford/ N.Y. etc., 1979), p.147.

${ }^{2}$ A. Momigliano, 'Persian Empire and Greek Freedom,' 1979, p.147.

${ }^{3}$ N.R.E. Fisher, Hybris, p.371. Cf. Herodotos, 7.16a-b.
} 
the best men and invest these with the power. For us we shall be among them, and among the best men it is likely that there will be the best counsels."

Dareios supported monarchy in the same discussion for polities and says that the best man, using the best judgment, will govern the people with perfect wisdom.

Herodotos, 3.82. "One could describe nothing better than the rule of the one best man; using the best judgment, he will govern the multitude with perfect wisdom, and make best concealed plans for the defeat of enemies."

The wisdom of the monarch, however, is one of two sides of a coin, and the monarch could err. Artabanus worried that Xerxes preferred what was more fraught with danger to himself and to the Persians.

Herodotos, 7.16a.2. "It was not that I heard harsh words from you that stung me so much as that, when two opinions were laid before the Persians, one tending to the increase of pride, the other to its abatement, showing how evil a thing it is to teach the heart continual desire of more than it has, of these two opinions you preferred that one which was more fraught with danger to yourself and to the Persians."

Artabanos summarizes and justifies twice, his earlier views, even while he comes to change his mind under pressure from the phantom. What he objects to is that it tends to increase Persian hybris and pleonexia. ${ }^{1} \mathrm{He}$ argues that the attempts to expand power had been disastrous on occasions in the past, and might be again in the present case.

In the case of Athens, however, the situation is not the same, since the people as a group made a decision. Lloyd-Jones made much of the Athenian citizen group, not the individual king, as an authority of political decision. ${ }^{2}$ According to him, the way in which the massacre at Melos is followed by the decision to invade Sicily, closely fitting as it does the pattern of Hybris and Ate which a study of the historians' predecessors might have led us to expect, makes it no easier to defend that thesis. ${ }^{3}$ The tragedy, however, is not of any man or men, but of Athens. Athens at first judges events rightly, but later is betrayed by hybris into justice, and loses the faculty of correct judgment.

And, according to him, Thucydides does not commit himself as to how far the tragedy of Athens can be put down to divine agencies, but Greeks who believed in such agencies held, from Homer's time on, that they worked upon the world not from outside but from inside, through human passions acting upon human minds.

\footnotetext{
${ }^{1}$ Cf. N.R.E. Fisher, Hybris, p.371f.

${ }^{2}$ Lloyd-Jones, Justice of Zeus, p.144. Cf. H.-P. Stahl, Thukydides (München, 1966), p.160f. Lloyd-Jones defined the world Thucydides presents, like the world presented by Herodotos, is a hard and ruthless world; it is the world of the traditional Greek religion. He says, whether Thucydides believed in the gods or not is not one of any great significance; for if he did reject them, it was the Greek gods, not any other gods whom he rejected.

${ }^{3}$ Lloyd-Jones, The Justice of Zeus, p.143. Lloyd-Jones also says that we should yet equally distort the balance of Thucydides' tragic history, if we were to argue that his whole presentation of Athenian imperialism was subtly hostile and his story was to warn against imperialism.
} 


\section{Success and Prosperity in Herodotos and Human Nature (Physis) in Thucydides}

The purpose of Herodotos writing history was that things done by man ought not to be forgotten in time, and that great and marvelous deeds should not lose their glory, including among other things the causes of their waging war on each other. ${ }^{1}$ The purpose of Herodotos was to avoid forgetting the matters of the past and not to leave great things meaningless.

Herodotos, 1.5.3 So much for what Persians and Phoenicians say; I have no intention of passing judgement on its truth or falsity. I prefer to rely on my own knowledge, and to point out who it was in actual fact that first injured the Greeks; then I will proceed with my history, and speak of small and great cities of men alike. [4] For many states that were once great have now become small; and those that were great in my time were small before. Knowing therefore that human prosperity never continues in the same place, I shall mention both alike.

Herodotos supposed a man's life as well as its history as a repetition or circulation of vicissitudes. E. Voegelin defines the historical viewpoint of Herodotus saying that human affairs are like a rotating wheel which does not permit a man to prosper all the time. ${ }^{2}$

Herodotos.3.80.2-4. [Otanes supporting democracy says] "It seems to me," he said, "that there can no longer be a single sovereign over us, for that is not pleasant or good. You saw the insolence of Cambyses, how far it went, and you had your share of the insolence of the Magus. [3] How can monarchy be a fit thing, when the ruler can do what he wants with impunity? Give this power to the best man on earth, and it would stir him to unaccustomed thoughts. Insolence is created in him by the good things which he has, while from birth envy is rooted in man. [4] Acquiring the two he possesses complete evil; for being satiated he does many reckless things, some from insolence, some from envy. And yet an absolute ruler ought to be free of envy, having all good things; but he becomes the opposite of this towards his citizens; he envies the best who thrive and live, and is pleased by the worst of his fellows; and he is the best confidant of slander."

Moreover, prosperity would cause jealousy of men or deities. Artabanos, Xerxes' uncle in Herodotos says the following, dissuading Xerxes' expedition.

Herodotos, 7.10e-f. ... You see how the god smites with his thunderbolt creatures of greatness and does not suffer them to display their pride, while little ones do not move him to anger; and you see how it is always on the tallest buildings and trees that his bolts fall; for the god loves to bring low all things of surpassing greatness. Thus a large army is destroyed by a smaller, when the jealous god sends panic or the thunderbolt among them, and they perish unworthily; for the god suffers pride in none but himself. Now haste is always the parent of failure, and great damages are likely to arise; but in waiting there is good, and in time this becomes clear, even though it does not seem so in the present.

\footnotetext{
${ }^{1}$ Herodotos, 1.1 .

${ }^{2}$ Eric Voegelin, The World of the Polis (Louisiana, 1957), p.337.
} 
Moreover, it is shown in Artabanos' statement dissuading Xerxes' expedition that to teach the heart continual desire of more than it has is a great evil, and the king has the initiative to prefer increasing pride or abating it. ${ }^{1}$ In the argument for polities, insolence(hybris) is connected with the kings, their prosperity and the jealousy of their gods. It is committed by individual kings, Cambyses, Magos, ${ }^{2}$ and Xerxes, who bring calamity upon themselves.

The purpose of Thucydides' History as precepts for future generations does not seem to greatly differ from that of Herodotos, when he says that the absence of the fabulous from his narrative will be profitable for whoever shall wish to have a clear view both of the events which have happened and will someday happen again in the same or a similar way. ${ }^{3}$

However, there is an essential difference between the two historians regarding the detailed content of precepts. In Thucydides, disaster caused by insolence does not (only) refer to the individual king, but to all mankind, even to the poor. ${ }^{4}$ Diodotos, who was opposed to the capital punishment imposed on the Mytilenians, described human nature, unchangeable even when faced with the critical situation of being sentenced to death, as following.

Thucydides, 3.45.4. " . ... as long as poverty gives men the courage of necessity, or fills them with the ambition which belongs to insolence and pride, and the other conditions of life remain each under the restraint of some fatal and master passion, only then will the impulse never want to drive men into danger."

\section{Sovereignty of the Persian King and the Athenians' Natural Law of Power}

Herodotus thought that the scale of the Persian War was greater than any other war which had occurred before. ${ }^{5}$ Thucydides also affirmed the Peloponnesian War on which he would write to be bigger than any other wars which the Greeks had known, for example, the Trojan War of Homer and the Persian War of Herodotus. ${ }^{6}$ Thus, the two historians had a similarity in being surprised at the scale of each war, but they show a great difference in defining the purpose and the cause of war.

Herodotos describes the outbreak of the Trojan War as being due to individual enmity. According to Herodotos, the Greeks invaded Asia before the Persians attacked Europe. They recruited a great armada for the sake of a Lacedaemonian woman, came to Asia, and destroyed the power of Priam. ${ }^{7}$ As

\footnotetext{
${ }^{1}$ Herodotos, 7.16.

${ }^{2}$ For insolence of Cambyses, cf. Herodotos, 3.16-38, 61-66; For insolence of Magos, cf. ibid. 3.65: $67: 73$.

${ }^{3}$ Thucydides, $1.21 .1 ; 1.22 .4$

${ }^{4}$ Cf. S. Hornblower, A Commentary on Thucydides, I (Oxford, 1997), p.436; as 'poor but not a bad man' in Dem. 21.95.

${ }^{5}$ Herodotos, 7.19ff.

${ }^{6}$ Thucydides, 1.1. Cf. Jack Riley, "Freedom and Empire," Thucydides Theory of International Relations, pp.122f.

${ }^{7}$ Herodotos, 1.4. Cf. D. Asheri, A. Lloyd, and A. Corcella, A Commentary on Herodotus, Book
} 
if the subject of insolence and being punished is individual, the cause of the Trojan War is defined as owing to private resentment.

In a similar context, Herodotos warned against the individual Xerxes' hybris. Then, the warning was not against the aggressive act itself but its immoderate degree. First of all, Herodotos cautioned against the inefficiency of the enormous scale of the army through the admonition of Artabanos, Xerxes' uncle, to Xerxes.

Herodotos, 7.49 "O king, there is no fault that any man of sound judgment could find either with this army or with the number of your ships; and if you gather more, those two things, which I speak of will become even much more your enemies. These two are the land and the sea. [2] The sea has no harbor, as I conjecture, that will be able to receive this navy and save your ships if a storm arises. Yet there has to be not just one such harbor, but many of them all along the land you are sailing by. [3] Since there are no harbors able to receive you, understand that men are the subjects and not the rulers of their accidents. I have spoken of one of the two, and now I will tell you of the other. [4] The land is your enemy in this way: if nothing is going to stand in your way and hinder you, the land becomes more your enemy the further you advance, constantly unaware of what lies beyond; no man is ever satisfied with success. [5] So, if no one opposes you, the increase of your territory and the time passed in getting it will breed famine. The best man is one who is timid while making plans because he takes into account all that may happen to him, but is bold in action."

When Xerxes fled after being defeated at Salamis, the Athenians wanted to chase him to the Hellespont, Themistocles dissuaded them saying that it is a fortunate chance to have driven away, a so mighty band of enemies, for it is not themselves who have won this victory, but the gods and the heroes, who deemed Asia and Europe too great a realm for one man to rule. ${ }^{1}$ Xerxes' hybris was not defined as individual perverseness but extended to the ambition to hold a larger territory.

On the other hand, there were men who could exceptionally be called 'free men' as elite aristocrats in Persia, ${ }^{2}$ while the subjects of the king of sovereignty were allegedly referred to as his 'slaves. ${ }^{3}$ Xerxes expected to impose a 'yoke of slavery' on all the peoples of the world. The Persian king's conquest requests a temporary increase of military power, but his rule was sustained

I-IV (Oxford, 2007), p.74. The abduction of Io is avenged by the Greeks' abduction of Europa. And with the third abduction of Medea by the Greeks, The abduction of Helen, the fourth, is supposed to be its justified Asian 'retribution.'

${ }^{1}$ Cf. Herodotos, 8.109.

${ }^{2}$ Herodotos.3.82.5. [statement of Dareios supporting monarchy] But (to conclude the whole matter in one word) tell me, where did freedom come from for us and who gave it, from the people or an oligarchy or a single ruler? I believe, therefore, that we who were liberated through one man should maintain such a government, and, besides this, that we should not alter our ancestral ways that are good; that would not be better.

${ }^{3}$ Cf. N.R.E. Fisher, Hybris, p.372. 
allegedly by traditional custom. Moreover, the power of Persia was many times greater than the target of its conquest as well as that of would-be slaves. ${ }^{1}$

The hybris of Thucydides, however, was not attributed to the individual king reigning over 'would be' slaves, but premised on the antagonism of two great powers. Both powers, Thucydides says(1.1.1.), were then at their best in preparedness for war in every way.

It relates to the collective, systematically organized military power of Athens, which justified the rule of power as a natural law, which could never be realized by mutual consent, but only by coercion. In this case, the authority of domination is not by an individual but by a community, Athenians. And the rule of power as a principle does not necessarily premise a large area such as Xerxes sought after, but could apply even to a small area, such as Melos.

At least a portion of the Athenian population tended to justify the rule of power, which accelerated the increase of military power and the pursuit of hegemony. And the authority of the rule was not an individual king but the Athenian community which was stronger.

According to Thucydides, the truest quarrel, though least in speech, was the growth of the Athenian power, which putting the Lacedaimonians into a position of fear, necessitated the war. ${ }^{2}$ He says that at the beginning of the Peloponnesian War both sides flourished in all manner of provision. Also he saw the rest of Greece siding with the one or the other faction, some then presently and some intending so to do. ${ }^{3}$

Gustafson, underscoring the collision among enormous powers, pointed out that the purpose of Thucydides was inquiring about the war between the two powers and helping the future generations to understand themselves by remembering the contemporary war affairs of the age of Thucydides. ${ }^{4}$

In fact Thucydides described the process by which military power had ever grown in the Greek world. According to him, originally there had not been large cities in Greece, military equipment being worthless and the people living dispersed without close relationships, even migrating. ${ }^{5}$ Then, no sooner than pirates had appeared the Minoan sea empire subjugated them, the strong came to subordinate the weak and the rich city the poor one.

According to N. Pappas, Thucydides (I.9) criticized Homer for having overlooked the real cause, and he himself found it in the power relationship between the party of Agamemnon and Troy. ${ }^{6}$ In the same context, Thucydides criticized Hellanicus of Lesbos as his statement was inaccurate and moreover devoid of concern for the Athenian growth of power. ${ }^{7}$ Then, Thucydides

\footnotetext{
${ }^{1}$ Cf. A.W. Gomme, A Historical Commentary on Thucydides, IV (Oxford, 1970), p.172. The Persian might was almost irresistible.

${ }^{2}$ Thucydides, 1.23.6.

${ }^{3}$ Thucydides, 1.1.1.

${ }^{4}$ L.S. Gustafson (ed.), Thucydides Theory of International Relations, p.2f. Cf. Thucydides, 1.1: 1.23 .

${ }^{5}$ Thucydides, 1.2 12. Cf. J. Riley, "Freedom and Empire," pp.122f.

${ }^{6}$ Cf. Nick Pappas, "Athens and America," in Thucydides Theory of International Relations, 234.

${ }^{7}$ Thucydides, 1.97.2.
} 
himself described the affairs during the past fifty years between the Persian War and the outbreak of the Peloponnesian War, which refer to the process of the growth of Athens. Moreover, at the beginning of the War, Thucydides describes the equipment for war of both sides, which attained a higher degree of preparation than any other had ever achieved, and which resulted to terrible destruction which had never been seen before. ${ }^{1}$

The growth of power advanced to an outspoken declaration of the natural law of power, which the Athenians insisted on against the Melians in $417 .^{2}$

Thucydides, 5.105.2. Of the gods we believe, and of men we know, that by a necessary law of their nature they rule wherever they can. And it is not as if we were the first to make this law, or to act upon it when made: we found it existing before us, and shall leave it to exist for ever after us; all we do is to make use of it, knowing that you and everybody else, having the same power as we have, would do the same as we do.

Thus, the insolence of the strong described in Thucydides is somewhat different from the hybris of Xerxes in Herodotus. Xerxes' hybris originated from the ambition for an inappropriately large territory on the one hand, and useless private insolence on the other. The conquest of Xerxes was to get sovereignty over 'earth and water' so as to collect taxes. And the problem was not the domination of the Persian king itself, ${ }^{3}$ but excessive desire which, going going beyond the human limit, extended over Asia to Europe. And as an example of private insolence, Xerxes punished the Hellespont with lashes and executed the workers who were charged with the responsibility of the disappearance of the pontoon bridge after the occurrence of a storm.

J.H. Finley recognized that there is a strong element of tragedy in Thucydides' History, but it would be incorrect to press this element of tragedy too far and above all, to imagine it as the key not merely to the method and spirit of the History, but even to its meaning. ${ }^{4}$ According to him, it was incorrect to believe that Thucydides is simply setting forth the old process of divine retribution known from tragedy, whereby hybris, insolence, ends in ate, disaster. For Thucydides saw that larger social forces take the place of gods in the History. Therefore it is a drama that is based on the confidence of men's powers. And, though Thucydides uses the means of tragedy to bring out the

\footnotetext{
${ }^{1}$ Thucydides, 1.89-118.

${ }^{2}$ Cf. Thucydides, 5.85 113.

${ }^{3}$ For the merits of monarchy, cf. Herodotos, 3.82, Dareios assumes the king will be 'the best'; Aristoteles, 1234b; W.W. How \& J. Wells, A Commentary on Herodotus (Oxford, 1912/ Ebook), 3.82.2. And the Spartans would ever prefer to accept monarchy rather than to suffer hard training to defend against the invasion of the Persians. Some Greek cities used to take part on the side of the Persians when there were inner conflicts among the Greeks themselves. The Thebans, who were in discord with the Spartans, and other tribes in mainland Greece voluntarily surrendered to the Persians. They preferred surrendering to the Persians to yielding to their hatred neighbors. In the Persian war, Argos kept neutrality due to the feud with the Spartans (Herodotos, 7.131).

${ }^{4}$ J.H. Finley, Thucydides, p.324f. According to Finley(p.324), on the one hand, the feeling that there is a strong element of tragedy in Thucydides' History is correct. On the other hand, however, his history is scientific as the forces at work are implicit in human nature and can be studied and recorded as something quite permanent (ibid. p.108f.)
} 
interplay between these forces and their human agents, still the substance of that pattern is the substance of history, not of drama

The religious, tragic framework in Herodotos is focused on the individual Xerxes, and the rule of power in Thucydides refers to the Athenians as a group. The deviance of the two historians, we could say, was due to the different social and political situations of each historian's life time.

\section{Hybris (insolence) and Phthonos (jealousy) in Herodotos}

There have been two views of interpretation regarding Herodotos. One is to regard a series of hybris and phthonos or nemesis as unfolded by the gods' will, which intervenes in the rise and fall of a state or an individual. The other one is to define hybris on a mundane level, which works in tragic human life, the vicissitudes of Imperialists, and the antagonism between Greeks and barbarous people.

Otherwise, Immerwahr provides three perspectives regarding the causality of Herodotos' history: 1) religious (F. Hellman), 2) a series of human offenses and vengeance (K. Pagel), 3) political (M. Immerwahr). ${ }^{1}$ De Romilly, however, developed the opinion that these three factors of causality are not irreconcilable. Defining various aspects of vengeance, tino, tisis (pay a price: 53 examples) and timoria, timorein (retribution: 60 examples) in Herodotos, she suggested that each historical causality could be connected with another one. $^{2}$

Fisher collected the traditional definitions of hybris and summarized them as being 'essentially an offence against gods." And, pointing to the inadequacies of this definition, he offers a substitute that seems to better cover the actual range of hybris words in Greek religious and secular life: 'Hybris is essentially a serious assault on the honor of another, which is likely to cause shame, and lead to anger and attempts at revenge.' If the 'other' whose honor is assaulted is a deity, then we have 'religious hybris (vs. 'secular hybris')."

However, Mikalson pointed out that the terms related to hybris are not to be found in Herodotos' accounts of the religious behavior of the individuals whose actions were notoriously impious or religiously problematic. ${ }^{5}$ Of

\footnotetext{
${ }^{1} \mathrm{Cf}$, J. de Romilly, 'La Vengeance comme explication historique dans l' oeuvre d'Hérodote,' REG 74 (1971), pp.314-37.

${ }^{2}$ J. de Romilly, 'La vengeance comme explication Historique dans l'oeuvre d'Hérodote,' $314 \mathrm{ff}$. Cf. In Thucydides the former does not appear, and the latter 54 examples presented.

${ }^{3}$ N.R.E. Fisher, p.1ff. That is, it is the act, word, or even thought whereby the mortal forgets the limitations of morality, seeks to acquire the attributes of the gods, or competes with the gods, or boasts overconfidently; or it is any act or word by which a man incurs the hostility of the gods, or even arouses their jealousy ...; or it is any 'excessive' act or word contrary to the spirit of the Delphic Oracle's pronouncements; it may even be no more than the possession of great good fortune, which in itself offends the gods.

${ }^{4}$ N.R.E. Fisher, p.1ff.; Cf. J.D. Mikalson, Herodotus and Religion in the Persian War (Cahpel Hill/ London, 2003), p.153f.

${ }^{5}$ J.D. Mikalson, Herodotus and Religion in the Persian War, p.153f. The individual refers to Croisos, Cambyses, Dareios, Xerxes, Artayctes, Cleomenes, etc. Mikalson' answer to the
} 
Herodotos' thirty-eight uses of hybris (hybris, hybristes, hybrizein, periybrizein, kathybrizein), he says, only one appears to be linked with human impieties. ${ }^{1}$ The fact that the hybris terms do not occur in such contexts does not, of course, preclude the presence of underlying hybris concepts such as the punishment of a hybristic individual by the gods.

Furthermore, Mikalson pointed out that Herodotos removed from his logoi (History) of 'old events' the gods associated with them in poetry along with their Homeric genealogies, attributes, and appearances. It may have been in part, he supposed, Herodotos' cosmopolitanism, as he also learned Persian and Egyptian logoi, which would hardly have featured the gods as the Greek poets imagined them. ${ }^{2}$ And, relevant to his expressed purpose of preserving 'what came to be from human beings,' the gods cult, not a poetic, Homeric-Hesiodic fiction, appear throughout Herodotos' histories.

However, in contrast to Mikalson's argument, in my opinion, the reason why Herodotos disassociated such 'old events' from the divine machinery the Greek poets put around them, could not be explained simply by his cosmopolitanism, or his concern about the gods of cult. He declared that the purpose of his History is to preserve 'what came to be from human beings,' including among others what was the cause of their waging war on each other, in order for it not to be forgotten in time. His purpose was not to feature the gods of Homeric-Hesiodic tradition, but to figure the cause of war which preferentially was attributed to hybristic human behavior.

On the other hand, Mikalson argues, it may be a particularly Herodotean twist that attributes failure and misfortune resulting in disaster primarily to the Persian Xerxes, and thereby helps save the Greeks. According to him, even if Herodotos 'believed' in 'the reversal of human fortunes' in divine phthonos, they are not part of a consistent theology, and for him they proved ultimately good, just, and helpful to the Greeks. They contributed, as did the gods of cult, to the Greek victories in the Persian Wars. ${ }^{3}$

In my opinion, however, the fact that Xerxes' hybris and failure is juxtaposed to the Greek victories does not mean that Herodotos took part with the Greeks as an ethnic group, but as the less prosperous, as in the period of the Persian War, the Greeks had not yet committed hybris.

Hybris results in not only punishment but phthonos (jealousy). According to Mikalson, ${ }^{4}$ the phthonos that Artabanos attributes to god is the emotion that may result when one's own prerogatives are being encroached upon by another, and it has elements of envy, ill will, self-protectiveness, and begrudgement, but allows no single English equivalent, certainly not 'envy.' Anyway, like hybris, phthonos pertains to the individual prosperous ruler, and not the Persians as a group, who are opposed to Greeks.

question why Herodotos chose not to define such impious behavior explicitly in terms of hybris, is that Herodotos is following popular (not poetic) religious convention. In lawcourts, for example, religious malefactors were to be charged with impiety (asebeia), not hybris.

${ }^{1}$ J.D. Mikalson, Herodotus and Religion in the Persian War, p.153.

${ }^{2}$ J.D. Mikalson, Herodotus and Religion in the Persian War, p.155.

${ }^{3}$ J.D. Mikalson, Herodotus and Religion in the Persian War, p.152.

${ }^{4}$ J.D. Mikalson, Herodotus and Religion in the Persian War, p.39f. 


\section{Tyche (Chance) in Thucydides}

Cornford saw Thucidides as a would-be scientific, nearly agnostic thinker who was still, contradictorily, fundamentally imbued with the religious/tragic patterns that led him to create the 'mythical' explanation of the rise and fall of Athens. ${ }^{1}$ Cornford's attention has particularly concentrated on the relation between the treatments of Melos and Sicily, and an inevitable process of infatuation, delusion, blindness and punishment was understood to be at work to explain the Athenian defeat in Sicily as well as the fall of Xerxes. ${ }^{2}$ And, though the gods played no part in Thucydides' History, Cornford says, an element of the incalculable nevertheless remained, and this element he called chance, tyche. ${ }^{3}$

On the other hand, Macleod asserted that the Athenian position is not a classic case of hybristic thinking, as it lacks the self-possessed arrogance and certainty of lasting success and superiority. ${ }^{4}$ Nor would their cautious assertions about the gods' clear failure to support the unjustly oppressed nor their skepticism about oracles, necessarily call hybris to mind, since hybris is not essentially a religious term, and would not a fortiori be felt to be such by Thucydides.

Fisher maintained on the one hand, according to Macleod, that hybristic attitudes of 'boundless self-confidence' or arrogance towards the gods are not evident in the case of the Athenians. ${ }^{5}$ The Athenians are sure of the rightness of their cynical views on morality and the world. So the attack on, and the destruction of, Melos were not acts of blind or rash over-confidence. ${ }^{6}$ There is little need, to see the deeds as typically hybristic in that sense. On the other hand, however, he says, that the Sicilian expedition is an instance of a fullscale act of imperialist hybris which resulted, partly for that reason, in the most surprising reversal of the whole war, and was itself the turning point in the war.

Furthermore, Fisher maintained, even if the Athenians were led from arrogance and cruetly, to over confident aggression, undoubtedly a strong form of hybris, which contributed heavily to a major disaster, one should not claim that the punishment was inevitable. Even the sophistic natural law of power is available in international relations, Fisher says, this does not inevitably mean the hybris-punishment pattern. The catastrophic disaster was due, partly, to culpable and pardonable errors, but partly also to other factors, for example, miscalculation, overconfidence about success, the leader's disability of persuasion, ${ }^{7}$ as well as the role of chance/fate. And the expedition should not be appraised by moral or religious view.

\footnotetext{
${ }^{1}$ F.M. Cornford, Thucydides Mythistoricus, pp.321-325 ; cf. Cf. N.R.E. Fisher, Hybris, p.390f.

${ }^{2}$ Cf. N.R.E. Fisher, Hybris, pp.386, .391.

${ }^{3}$ F.M. Cornford, Thucydides Mythistoricus, p.312.

${ }^{4}$ C.W. Macleod, Collected Essays, p.62. Cf. N.R.E. Fisher, Hybris, p.400.

${ }^{5}$ N.R.E. Fisher, Hybris, p.400ff.

${ }^{6}$ Fisher (Hybris, p.400) says that the attack on, and the destruction of, Melos was not of typical typical hybris, as the Athenians were virtually assured of 'success' one way or another, even though there was a considerable miscalculation and folly from a longer point of view.

${ }^{7}$ Pericles could dissuade the hybris of people for further military expansion in war situation
} 
Marinatos and Rawlings also disclaimed the view that hyris inevitably causes punishment. They suggest that, in Herodotos there are appropriately great punishments stemming from the gods, but in Thucydides 'Tyche' has changed sides, in addition to the complex of military and political reasons, in order that Athenians should be greatly punished for their great offences ${ }^{1}$

Marinatos and Rawlings contrasted deity with tyche. In my opinion, however, to understand properly the meaning of tyche, three points should be underscored. First, tyche in Thucydides, irrelevant to the will of the gods on the one hand, and/or human preparation or calculation on the other, bring about unexpected, not only disaster but good luck. Diodotos in Thucydides says that not only hope and cupidity but Fortune, too, powerfully helps the delusion, and by the unexpected aid that she sometimes lends, tempts men to venture with inferior means. ${ }^{2}$ Cleon in the same work mentioned that great good fortune that comes suddenly and unexpectedly tends to make people insolent. It means, great good fortune could come suddenly and unexpectedly. ${ }^{3}$

Tyche has nothing to do with human will, and does not permit any calculation. The Spartan king, is proud of the Spartans, who keep moderation in front of the vicissitudes of fortune. ${ }^{4}$ It means that even if humankind cannot control fortune, it is himself who devises countermeasures. According to Herodotos, however, even if an unexpected good fortune comes, it is attributed to the gods' thanks or the heroes, by whose help, Themistocles regards, the unexpected victory of Salamis was gained. ${ }^{5}$ In Herodotos the role of humankind as well as unexpected fortune is diminished.

The second point to consider regarding tyche is that the danger created by human error and unexpected tyche increased in situations of war rather than peace. According to Hornblower, Thucydides thought that war aggravates the effects of pleonexia. ${ }^{6}$ And Macleod sees in the Corcyra chapters a more pessimistic belief that war undoes progress, or rather induces a specially twisted sort of progress. ${ }^{7}$ Thucydides describes regarding the civil war of Corcyra that war is a rough master, entailing sufferings and taking away daily wants, and creates in most people a temper that matches their condition. In peace and prosperity states individuals have better sentiments, even if the nature of mankind remains the same. ${ }^{8}$

The third one is that tyche in Thucydides refers to all mankind, rich and poor, the prosperous and the poor, which differs from human or gods'

(ibid. 2.63), but Nicias could not do so because of a deficiency of persuasion (Thucydides, 2.65).

${ }^{1}$ N.Marinatos Kopff \& H.R. Rawlings, 'Panolethria and Divine Punishment,' Parola del Passato, 33 (1978), p.331ff.

${ }^{2}$ Thucydides, 3.45.5-7. Cf. Thucydides, 4.18.4; S. Hornblower, A Commentary on Thucydides, (Oxford, 1991), p.128.

${ }^{3}$ Thucydides, 3.39.4. Cf. Ibid. 1.84.2.

${ }^{4}$ Thucydides, 1.84.1-2.

${ }^{5}$ Herodotos, 8.109.2-3. For the help of heroes and gods mentioned, cf. ibid. 8.143.

${ }^{6}$ S. Hornblower, Thucydides (Duckworth, 1986), p.188.

${ }^{7}$ C. Macleod, Collected Essays, p.125ff.

${ }^{8}$ Thucydides, 3.82.2. Cf. S. Hornblower, A Commentary on Thucydides, I, p.482; Thucydides, 3.45.4. 
phthhonos against the rich or prosperous. As Macleod says, the self-possessed arrogance and certainty of lasting success are not inevitably available for the Athenians.

\section{Conclusions}

In both the Histories of Herodotos and Thucydides, we could see that mans' insolence brings about disaster to humankind himself. The mechanism with which the insolence is embodied in real situations, however, differs according to who has political authority at his/her command.

Thucydides used to be defined as a historian who focused more on the political and military fields, than Herodotos whose work tended to be regarded as having a religious, tragic framework. In my opinion, this kind of contrast is due to the different social situations of each historian's life time, rather than private tendencies of writing. Thucydides realized the increased social importance of militarism to such a degree which had never been before.

The hybris (insolence), phthonos, ate (or nemesis) in Herodotus frequently refers to the individual, Xerxes, and his 'hybris' does not refer to the monarchic domination itself, but his excessive desire for an over-exaggerated and ineffective scale of territory, which leads him to invade so far as to Hellas. The monarchy itself is not so bad, having strong points as well as weak, likewise democracy and oligarchy. This is proved in Herodotus' own account (III.80 83), where he discussed the relative merits of each polity. Moreover, when Mardonios tried to persuade the Athenians into surrendering to the Persian king, Xerxes, he argued for coexistence and a peaceful life. ${ }^{1}$

The Persian king's conquest required a temporary increase of military power, but his rule was sustained by traditional customs under sovereignty. The ruled that once subjected to the king, were customarily regarded as 'king's slaves', who were not always oppressed or controlled by military power, but were dominated by traditional custom.

The hybris of Thucydides, however, was not attributed to the individual king against the slaves, but premised on the antagonism of two great powers. It relates to the collective, systematically organized military power of Athens, which justified the rule of power as a natural law, which could never be realized by mutual consent, but only by coercion. And the rule of power as a principle does not necessarily premise a large area such as Xerxes sought after, but could apply even to a small area, such as Melos.

The military power of the Athenian antagonistic partner almost equals that of the Athenians. So the Athenian militaristic hegemony could be sustained only by the superiority of military power, irrelevant to any traditional custom. In the situation of balance of power, human errors or insolence could bring about fatal disasters much more in war time than peace, as the risk of human mistakes increases in the former.

The punishment in Herodotos was inflicted by deity against the hybris

${ }^{1}$ Cf. Herodotos, 8.140 
committed by an individual, but in Thucydides by Tyche (Fortune) which alters situations unexpectedly and causes disaster to a community, irrelevant of whether one commits hybris or not.

The difference presented in the concepts of 'hybris' between the two historians reflects the difference of social environments in which each historian lived. Militarism on the principle of 'rule of power' as a natural law was not yet widely prevalent in the age of Herodotos. The war was not waged between two gigantic powers and the conquered would be transferred to become the slaves of the Persian king. The true ambition of the Persian king was a larger territory and the might of the conquered, those who would allegedly become slaves, could not match his military.

After the Persian War, however, the Delian League around the Aegean Sea was organized under the hegemony of Athens. The creation of the Delian League provided the momentum for the growth of professional mercenary marine soldiers. In Thucydides two huge powerful sides rivaled each other, and territorial extension was not a matter of priority.

\section{References}

Primary Sources

Aristoteles, Politika (Politics)

Herodotos

Thucydides

\section{Secondary Sources}

Asheri, D, A. Lloyd, and A. Corcella. A Commentary on Herodotus, Book I-IV. Oxford, 2007.

Cornford, F.M. Thucydides Mythistoricus. 1907 ed. London, 1965.

de Romilly, J., "La Vengeance comme explication historique dans l'oeuvre d'Hérodote," REG 74. pp.314-336, 1971.

de Romilly, J. Thucydides and Athenian Imperialism. Oxford, 1963.

Finley, John H. Thucydides. Michigan, 1967.

Fisher, N.R.E. Hybris. Teddington, 1992.

Gomme, A.W. A Historical Commentary on Thucydides, IV. Oxford, 1970.

Gustafson, L.S. Thucydides Theory of International Relations, 2000 ed. Luisiana.

Hornblower, S. A Commentary on Thucydides, I, Oxford, 1991.

How, W.W., and J. Wells. A Commentary on Herodotus. Oxford, 1912, e-book.

Lloyd-Jones, H. Justice of Zeus. Berkely/ Los Angeles, 1973.

Macleod, C.W. Collected Essays. Oxford, 1983.

Marinatos, N. Thucydides and Religion. Konigstein, 1981.

Marinatos Kopff, N. and H.R. Rawlings. 'Panolethria and Divine Punishment: Thuc.7.87.6 and Hdt.2.120.5,' PP 33. 1978.

Mikalson, J.D. Herodotus and Religion in the Persian War. London: Cahpel Hill, 2003.

Momigliano, A. Studies in Historiography. N.Y, 1966. 
Momigliano, A. "Persian Empire and Greek Freedom." In The Idea of Freedom: Essays in Honour of Isaiah Berlin, Alan Ryan ed. (Oxford/ N.Y. etc. pp.139-151, 1979.

Pappas, Nick. "Athens and America." In Thucydides Theory of International Relations, L. S. Gustafson ed. Luisiana. pp.221-245.

Riley, Jack. "Freedom and Empire." Thucydides Theory of International Relations. L. S. Gustafson ed. Luisiana. pp.117-150, 2000.

Voegelin, Eric, The World of the Polis. Louisiana, 1957. 
